\title{
WHIPLASH INJURIES
}

\section{TREATMENT RELATED TO PATHOLOGY AND STAGES OF HEALING}

\section{by Helen David, BSc (Physiotherapy) Witwatersrand, Private Practitioner, Johannesburg}

The term "whiplash" is used to describe neck injuries resulting from rapid acceleration-deceleration forces, usually due to motor vehicle accidents (MVA's). Whiplash patients present a formidable challenge to physiotherapists because of the extremely variable range of clinical presentations and owing to the unpredictability of the end result of treatment.

Whiplash patients have been labelled hysterical, neurotic, if not frankly dishonest ${ }^{1}$ as they often continue to complain of pain and other symptoms for unexpected lengths of time, even well after the settlement of any court cases.

Recent literature has provided some clues to this problem. In addition to the injuries to muscles, ligaments and joints, Twomey and Taylor ${ }^{2}$ have shown that there is a strong possibility that whiplash may cause rim lesions of the discs. These rim lesions are linear clefts within the cartilage plate near the vertebral rim and extending into the annulus. According to an experimental study in sheep by Osti et $\mathrm{al}^{3}$, such lesions do not heal (except for the outermost part of the annulus) but continue to extend within the disc over the year following the injury ie., a process of degeneration is set in motion. This is one possible explanation for persistent symptoms in whiplash patients.

Another possibility is that injuries may be more extensive than suggested by radiographs and may include disc lesions and fractures of bony elements. Jonsson et $\mathrm{al}^{4}$ studied 22 cervical spines from MVA victims with fatal injuries. They describe injuries found at autopsy which had been missed on post-mortem $X$-rays. In total, there were 245 bone and discoligamentous lesions and even on re-evaluation of the radiographs, only four of these defects were detected. Coles ${ }^{5}$ mentions an instance of an undetected fracture-dislocation of the $\mathrm{C} 6 / 7$ vertebrae in a whiplash patient which was subsequently found on further X-ray, six weeks after the MVA.

Twomey and Taylor 2 also found cases of blood within the outer annulus (bruising) and haemarthrosis and capsular tears of

\section{ABSTRACT}

Whiplash patients present a challenge to physiotherapists because of the variability of clinical presentations and the unpredictability of the outcome of treatment. Recent literature, which may provide some clues to this situation, is discussed. The clinical implications are that physiotherapy treatments should be carefully graded and non-aggressive. Twelve whiplash patients were treated according to these guidelines and their data were analysed.

\section{OPSOMMING}

Pasiēnte met 'n sweepslagbesering is ' $n$ uitdaging vir fisioterapeute as gevolg van die wisselende kliniese beeld en die onvoorspelbaarheid van die effek van behandeling. Onlangse literatuur wat moontlike redes vir die situasie aanvoer, word bespreek. Die kliniese implikasie is dat fisioterapie baie versigtig toegepas moet word en glad nie aggressief mag wees nie. Twaalf sweepslag pasiēnte is behandel volgens hierdie riglyne en hul resultate is ontleed. the facet joints, which would not show up on routine X-rays.

The implication of these studies is that whiplash patients should be handled with extreme care as they may have extensive injuries to many structures. Any aggressive treatment including manipulations would thus be strongly contra-indicated at all stages as this might cause further damage to structures, in particular the disc which does not heal readily, and might precipitate early degeneration with associated pain and other symptoms.

In the treatment of whiplash patients, in addition to considering all possible elements of the neuro-muscular-articular systems which may have been injured, it is also vital to consider where the whiplash patient is in the total spectrum of the Stages of Healing as described by McGonigle and Matley ${ }^{6}$. Briefly summarised these are:

1. Inflammatory Stage - wound sealing, phagocytosis of bacte ria and dead cells, re-establishment of blood supply so that repair begins. This stage lasts from 24-48 hours to two weeks or more.

2. Fibroblastic Stage - re-epithelialisation, wound contraction, collagen production. This stage starts from a few days after injury and continues for 2-4 weeks.

3. Remodelling Stage - final orientation and arrangement of collagen fibres. This takes from 6-12 months and successful healing results in a scar of sufficient tensile strength and similar to normal tissue in length, alignment and mobility. However, at the beginning of the remodelling phase the tensile strength of the collagen may be as little as $15 \%$ of normal and this implies that the treatment progression should be carefully graded. In particular, excessive loading or overstretching should be avoided.

\section{AIMS}

1. To analyse the data of a group of whiplash syndrome patients whose treatment was based on the principle taking into account any possible damage to neuro-muscular-articular systems.

2. To suggest an appropriate approach to treatment in these cases.

\section{MATERIAL AND METHODS}

Twelve whiplash patients were selected retrospectively, with their consent, for this study. They were selected on the basis of their arrival for the initial treatment during a particular time period. Detailed records of their treatments were kept and a follow-up was carried out approximately one year after treatment had been terminated.

There were ten females and two males. Their ages ranged from 17 to 68 years, with all except one being below 45 years of age.

The treatment programme followed the basic guidelines as described in Appendix A

Specific treatments were based on the concepts of Maitland ${ }^{7}$ Edwards ${ }^{8}$, Janda ${ }^{8}$, Elvey ${ }^{8}$, Butler ${ }^{9}$, Knott and Voss ${ }^{10}$, Travell and Simons ${ }^{11}$, Rocabado ${ }^{12}$.

\section{RESULTS}

As expected, the patients raried enormously in all aspects, viz.: a. presenting symptoms

b. length of time from MVA to commencement of physiotherapy c. number of treatment sessions to recovery*

d. time to recovery* 
(*"recovery" was defined as:

Subjectively: "fine"

Objectively: full-range pain free active movement;

pain free passive accessory movement to IV (but not IV++);

normal length of muscle, connective tissue and neural tissue.)

Based on a combination of points a), c), and d) above, patients were classified into four categories of whiplash injury, viz., Minimal, Mild, Moderate/Severe and Severe. See Table I.

Points b), and d) above were considered in relation to the stages of Healing (See Figure 1).

Follow-up contacts were made approximately one year after completion of physiotherapy treatments and the results are summarised in Table II.

\section{DISCUSSION}

An analysis of this small sample of Whiplash Injury patients supports the commonly held views that these patients differ greatly in their clinical presentation, in the amount of treatment required and the length of time to recovery. Patients also arrive for physiotherapy treatment at very varying times after the date of the MVA ie., at differing points in the stages of healing.

These differences make it impossible to lay down firm rules for treatment, such as for how long a soft collar should be worn or when to start working into resistance. However, based on the studies of Twomey and Taylor ${ }^{2}$, Osti $\mathrm{et} \mathrm{al}^{3}$ and Jonsson $\mathrm{et} \mathrm{al}^{4}$, a treatment regime was planned and has been in use by the author for some time. The 12 patients who were included in this study were all treated according to these guidelines, viz.:

1. There should be a balance between rest and immobilisation on the one hand and a carefully graded movement programme on the other.

2. Any aggressive treatment including manipulation Should be avoided at all stages.

3. All elements of the neuro-muscular-articular systems should be considered in the programme.

The study by McGonigle and Matley ${ }^{6}$ states that it may take up to 6-12 months for healing tissue to attain full strength and this supports the conservative approach which had been followed in these 12 cases.

In this study the follow-up of the 12 patients, approximately one year after termination of physiotherapy treatment, indicated good results in the majority of cases. (see Table II).

Both patients from the Minimal classification, two from the Mild group and two from the Moderate/Severe group had been absolutely fine since termination of treatment. (One of these had suffered a fracture of the $\mathrm{C} 7$ vertebral body). These results were classed as good.

One patient from the Moderate/Severe classification had been symptom free for six months, then developed a local ache one day after sitting with his head in an awkward position for hours. This responded immediately to postural advice from a chiropractor and did not recur and was thus considered to be a good result. Another patient from this category was symptom free except after a very long day's drive, when she would develop mild local pain. Her occupation involves a lot of driving and as she had a history of two MVA's, the second just as she was recovering from the first, and as she runs, cycles and does a great deal of driving, this was also considered to be a good result.

One patient in the Mild group was symptom free for four months after termination of physiotherapy but then developed a local pain and stiffness. He was treated by a chiropractor who

\begin{tabular}{|c|c|c|c|c|}
\hline \multicolumn{5}{|c|}{ TABLE I: SUMMARY OF 12 WHIPLASH PATIENTS } \\
\hline Classification & Minimal & Mild & Maderate/severe & Severe \\
\hline Number of cases & 2 & 3 & 4 & 3 \\
\hline Symptoms & $\begin{array}{l}\text { Locol pain \& } \\
\text { stiffness }\end{array}$ & $\begin{array}{l}\text { Lacal pain \& } \\
\text { stiffness } \\
\text { headaches }\end{array}$ & $\begin{array}{l}\text { variable: } \\
\text { Local pain \& siffness } \\
\text { Headaches. dizzy } \\
\text { etc. } \\
\text { parcestheisa } \\
\end{array}$ & $\begin{array}{l}\text { variable: } \\
\text { dysfunction } \\
\text { neurological } \\
\text { cord }\end{array}$ \\
\hline $\begin{array}{l}\text { Treatment } \\
\text { commenced }\end{array}$ & $\begin{array}{l}\text { day } 2 \\
\text { day } 6\end{array}$ & $\begin{array}{l}\text { Day } 1 \\
\text { day } 4 \\
\text { day } 7\end{array}$ & $\begin{array}{l}\text { Doy } 4 \\
\text { week } 4 \\
\text { week } 5 \\
\text { week } 6\end{array}$ & $\begin{array}{l}\text { Week } 3 \\
\text { month } 2 \\
\text { month } 6\end{array}$ \\
\hline $\begin{array}{l}\text { Number of } \\
\text { treatments to } \\
\text { recovery }\end{array}$ & \pm 3 & \pm 6 & $10-12$ & $\begin{array}{l}>12 \text { - ongoing } \\
\text { maintenance) }\end{array}$ \\
\hline Time to recovery & 1 week & $\begin{array}{l}10 \text { days }-3 \\
\text { weeks }\end{array}$ & $\begin{array}{l}5 \text { weeks }-3 \text { months } \\
\text { (one cose 2nd MVA } \\
\text { ofter } 3 / 12 \text {, thus } \\
6 / 12 \text { totol) }\end{array}$ & $\begin{array}{l}\text { > } 3 \text { months } \\
\text { incomplete } \\
\text { recovery }\end{array}$ \\
\hline
\end{tabular}

KEY IREAIMENT PERIOD FOR A PARTICULAR PAIIENT

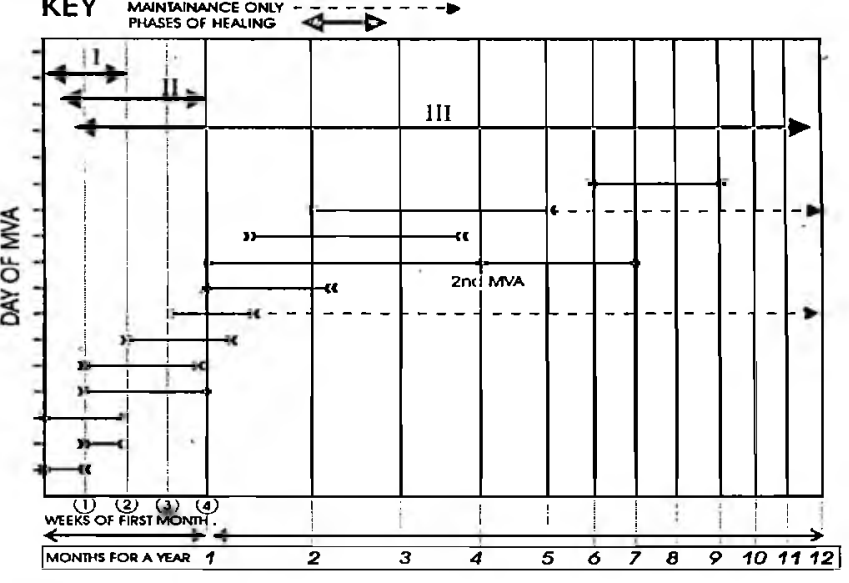

Figure 1: Stages of healing

\begin{tabular}{|c|c|c|c|}
\hline \multicolumn{4}{|c|}{ TABLE II: RESLUIIS OF FOLLOW-UP } \\
\hline Patient & Clossification & 1-year follow-up & Result of physiotherapy \\
\hline 1 & Minimal & Fine & Good \\
\hline 2 & Minimal & Fine & Good \\
\hline 3 & Mild & Fine & Good \\
\hline 4 & Mild & Fine & Good \\
\hline 5 & Mild & $\begin{array}{l}\text { Fine 4/12. Locol stiffness \& pain. } \\
\text { Chiroproctor manipulated repeatedly } \\
\text { only tronsient relief }\end{array}$ & Poor \\
\hline 6 & Moderate/severe & Fine & Good \\
\hline 7 & Moderate/severe & Fine & Good \\
\hline 8 & Moderate/severe & $\begin{array}{l}\text { Fine } 6 / 12 \text {, mild local ache. } \\
\text { Chiropractice \& postural advice - fine, } \\
\text { ind scubo-diving. }\end{array}$ & Good \\
\hline 9 & $\begin{array}{l}\text { Moderote/severe } \\
2 \text { MVA's in } 3 \\
\text { months }\end{array}$ & $\begin{array}{l}\text { Fine except ofter long drives - mild } \\
\text { local poin. Drives ++, runs, cycles. }\end{array}$ & Good \\
\hline 10 & $\begin{array}{l}\text { Severe (\# } \\
\text { Odontoid pec) } \\
\end{array}$ & $\begin{array}{l}\text { Locks full rotation, otherwise fine. Indl } \\
\text { exercise closses \& swimming. }\end{array}$ & Acceptoble \\
\hline 11 & $\begin{array}{l}\text { Severe } \\
\text { (\#/dislocotion } \\
(6 / 7-\text { fusion })\end{array}$ & $\begin{array}{l}\text { Some residual weakness intrinsics left } \\
\text { hond. Stiff occosional ache of cervico- } \\
\text { thorocic junction. Whaks, oquorabics, } \\
\text { core for grondchildren }\end{array}$ & Acceptoble \\
\hline 12 & $\begin{array}{l}\text { Severe (oxillory } \\
\text { nerve domoge) }\end{array}$ & $\begin{array}{l}\text { Fine in relation to cervical headaches. } \\
\text { Deltoid still not functional. Awoiting } \\
\text { spontaneous recovery or possible neve } \\
\text { groff. }\end{array}$ & Acceptoble \\
\hline
\end{tabular}


manipulated his neck repeatedly, with transient relief only. This was considered a poor result, largely from the point of view that the patient had not adequately understood the potentially serious nature of his injury and the need for non-aggressive management. Although this had been explained to him, it may have been advisable to contact the patient at intervals to ensure that healing was continuing as it should.

The three patients from the Severe classification had not recovered completely by the follow-up. The patient who had fractured the odontoid peg of the $\mathrm{C} 2$ vertebra and had spent two months in skull traction and two months in a firm brace did not regain full range of upper cervical rotation. In all other respects she was symptom free and leads a full life including exercise classes and swimming. The 68 year old patient with a fracture-dislocation of the $\mathrm{C} 6 / 7$ vertebrae with spinal cord involvement had undergone spinal fusion and had residual weakness of the intrinsic muscles of the left hand and some cervico-thoracic junction area stiffness for which she receives maintenance physiotherapy. However, she is functional, does pool exercise and swimming and looks after two grandchildren. The 17 year old patient whose axillary nerve was damaged in the MVA is still awaiting recovery of this nerve or possible nerve grafting. Her original neck and headache symptoms are fully recovered but she receives maintenance physiotherapy to prevent shoulder problems because of the non-functioning deltoid muscle. These three results were considered to be acceptable in view of the serious nature of the original injuries.

It would thus appear that this study supports the rationale suggested by the literature $(2,3,4,5)$ ie., that a conservative approach to the whiplash syndrome, where the extent of injuries is never certain, is the appropriate one.

\section{CONCLUSION}

Patient with whiplash injuries present a challenge to physiotherapists. In order to treat them with the best possible chance of good result, the following points should be borne in mind:

1. There must be a balance between immobility and support, and a carefully graded movement programme.

2. All structures/systems which may be damaged must be considered.

3. The stages of healing must be considered. In view of the length of time to full strength of the new collagen, it would seem advisable to check on the patient at intervals for up to a year in order to ensure that all is progressing as it should and to take appropriate steps should problems arise.

4. There is not place for aggressive treatment, especially manipulation, in the early stages, and perhaps not for a year or more as this may increase the size of any existing rim lesions and hasten discogenic degeneration. More research is needed in this respect.

5. Patients should be educated as to the possible extent of their injuries and the length of time until healing is complete. This should include advice on the avoidance of situations which may jeopardise optimal recovery such as contact sports or any aggressive treatment including manipulation of the cervical spine.

\section{REFERENCES}

1. McNab I. Acceleration Injuries of the Cervical Spine. J Bonc Jt Surg 1964;46A:1797-1799.

2. Twomey L T, Taylor J R. The Whiplash Synd rome: Pathology \& Physical Treatment. Jof Manual and Manip Ther 1993;1(1):26-29.
3. Osti O L, Vernon-Roberts B, Fraser R D. Anulus Tears \& Intervertebral Disc Degeneration: An Experimental Study using an Animal Model. Spine 1990;15(8):762-767.

4. Jonsson H, Bring G, Rauschning $W$ et al. Hidden Cervical Spine lnjuries in Traffic Accident Victims with Skull Fractures. I Spinal Disord $1991 ; 4(3): 251-263$.

5. Coles M. First Do No Harm. Physio Fortum 1995;9(4):5.

6. McGonigle T, Matley K W. J of Manual and Manip Ther 1994;2(2):55-62.

7. Maitland G D. Vertebral Manipulation. 5th ed London: Butterworths, 1986.

8. Grant R (Ed) Physical Therapy of the Cervical and Thoracic Spine. New York: Churchill Livingstone 1988. Chapter 8 (Edwards BC), 9 (Janda V), 10 (Elvey Retal).

9. Butler D S. Mobilisation of the Nervous Systent. Edinburgh: Churchill Livingstone 1991.

10. Knott M, Voss D E. Proprioceptive Neuromuscular Facilitation. Patterns and Techniques. 2nd ed New York: Harper and Row, 1968.

11. Travell ] G, Simons D G. Myofascial Pain and Dysfunction. The Trigger Point Manual. Baltimore: Williams and Wilkins, 1.983.

12. Antoniotti T, Rocabado M. Exercise and Total Well Bcing for Vertebral and Craniomandibular Disorders. Tucson: IFORC Publications, 1990.

\section{TREATMENT OF "WHIPLASH" INJURIES \\ EARLY STAGES}

- Rest eg., time off work

- Immobilisation eg., soft collar

- Modalities to decrease oedema and assist healing eg., laser, ice, ultrasound, IF.

- Gentle active movement - an example Home Exercise Programme follows:

Lying on back, head on pillow, knees bent, do each exercise 3-5 times, three times daily.

Gently and slowly move in the following ways, stopping at point where pain just starts (or if there is pain at rest, stopping at point where pain just starts to increase):

1. Chin tuck towards chest.. Chin raise to look up at ceiling.

2. Head turn to left. Head turn to right.

3. Slide left hand down towards feet.. Repeat with right hand.

4. Shoulder blades back towards each other and down (in a "V" shape).

5. Straighten left knee and then bend it again. Straighten right knee and then bend it again.

6. Left ear towards left shoulder. Right ear towards right shoulder.

7. Progress to combinations of the above eg., 3) and 4). 1) and 5).

- Advice re: Posture - Standing, sitting, sleeping, work station.

- Emphasis on stabilisers according to Janda Concept.

\section{LATER STAGES}

Gradually decrease the use of the collar and increase free active movement.

Remember to address all systems in the rehabilitation programme ie., joint, neural tissue, muscle, connective tissue, disc.

Also take appropriate care if vascular or bony damage may be present.

Joint - accessory and physiological mobilisations and later combined movement patterns.

Neural - use distal components and progress to ULTT and slump.

Muscle - Free movement, then isometric resistance, then PNF patterns.

Stretches.

Connective tissue - myofascial release. Stretches.

Disc - advice, posture, ADL, any appropriate treatment if required. eg., traction.

All patients should be instructed in neck care, avoidance of potentially harmful situations (including manipulations) and total posture patterns. An appropriate exercise class and lecture/slide show is useful. 